\title{
Szélcsatornaépítés a gyakorlatban
}

\section{Wind tunnel making in practise}

\author{
A. KOSTYÁK ${ }^{1}$, F. SZODRAI ${ }^{2}$ \\ 1University of Debrecen, attila.kostyak@gmail.com \\ 2University of Debrecen, szodrai@eng.unideb.hu
}

Absztrakt. Cikkünkben a kis sebességü szélcsatornával foglalkoztunk. Célunk az volt, hogy létrehozzunk egy olyan nyitott rendszerü szívott légcsatornát, melynek segítségével a későbbiekben méréseket végezhessünk. Ehhez szükséges volt a szélcsatorna prototípusának megalkotása és kalibrációs mérések elvégzése, hogy a mérōtérben uralkodó áramlásviszonyokat feltérképezzük. A szélcsatornánkban teljesültek várakozásaink, de számos ponton van tér még a fejlesztésre, amit a levont tapasztalatok alapján kívánunk megtenni.

Abstract. In this paper, we examined the low speed wind-tunnels. Our goal is to construct an open flow system windtunnel that can be utilized in our measurements. To make such a wind-tunnel we needed to build a prototype and calibrated with the help of measurements. Than we determined the flow at the area of measurement. Finally results of the measurements satisfied our expectations. Although there is still much more in development that we would like to do based on the newly gained experience.

\section{Bevezetés}

A szélcsatornákat légnemü közegek áramlásának vizsgálatának fontos eszköze. A vizsgáltok során szükséges, hogy a mérőtérben az általunk kívánt áramlási kép előállítható és reprodukálható legyen, ezáltal alapot adva az összehasonlításoknak, a különböző hatások modellezése érdekében. Dolgozatomban a szívott rendszerü nyitott áramú szélcsatornákat vizsgáltam. Ahhoz, hogy konkrét méréseket végezhessünk és a szélcsatorna rendszerek részegységeit megvizsgálhassuk saját szélcsatornát építettük. Dolgozatunkban a szélcsatorna prototípus megépítésének kihívásait és a benne végzett mérések bemutatását prezentáltuk.

\section{Szélcsatorna építés}

A szélcsatorna típusok közül a nyitott rendszerü, szívott szélcsatornák a müszakilag egyszerübb és könnyebben kivitelezhető típusok, így ezt az elrendezési formát választottam.

\subsection{Részegységek}

Az építés során 2db KLIMAWENT gyártmányú WP-11 radiális lapátozású csőventilátor állt rendelkezésünkre. Ahhoz, hogy a lehető legnagyobb térfogatáramot tudjuk előálítani a szélcsatornában a 
ventilátorok párhuzamos kötését alkalmaztuk. Mivel a ventilátorok azonos típusúak, így nyomásgörbéjük megegyezik, így párhuzamos kapcsolás esetén munkapontjuk is azonos.

A méröteret a ventilátor teljesítményéhez próbáltuk igazítani. A hasznos mérőtér $400 \mathrm{~mm}$ széles és $550 \mathrm{~mm}$ magas négyszög keresztmetszettü. A mérötér $1 \mathrm{db} 1,5 \mathrm{~m}$ hosszú légcsatorna darabból került kialakításra. Azért, hogy az áramlást a rögzítés technikai elemekkel és a méröegységek részeivel minél kevésbé zavarjuk meg, a légcsatorna aljába egyedi dobozt helyeztünk el.

Az egyedi doboz pontosan illeszkedik a mérőtérként használt légcsatornához, ezáltal álpadlót hoztunk létre.

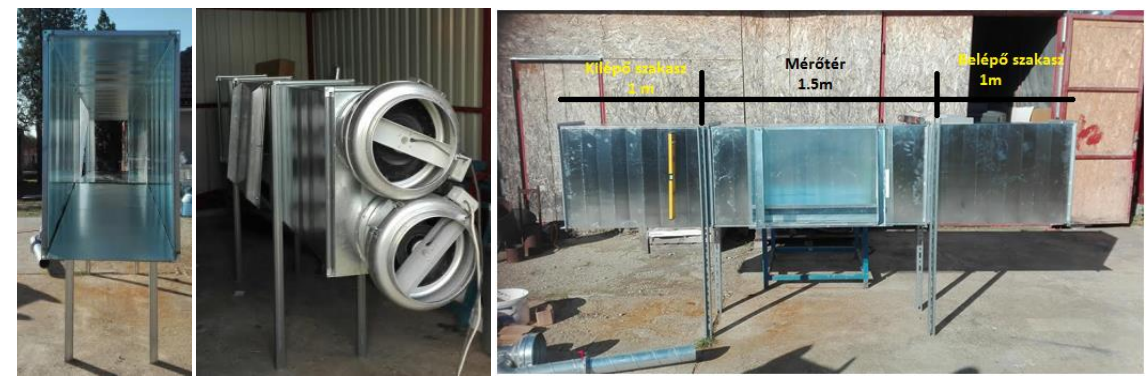

\section{1. ábra: Szélcsatorna kialakitása}

A szélcsatorna négy szakaszból áll. Mind a 4 szakasznak az alapja 400•700-as négyszög keresztmetszetü légcsatorna. A fenti képen a szélcsatornához tartozó 3 szakasz látható. A 4. szakasz, a ventilátor fogadó idom.

Azért, hogy a beáramló levegő ne közvetlenül a mérőtérbe kerüljön $1 \mathrm{~m}$ hosszú belépő szakaszt helyeztünk a rendszerbe. A belépő szakasz végén, hogy elkerüljük a hirtelen keresztmetszett szükülést, amit a mérötérbe helyezett doboz okozna, egy egyedi kiegészitő elemet helyeztünk a légcsatorna aljára. Az elem egyenletes szükítést valósít meg a belépő szakaszon. A kezdeti 400 700 belépő keresztmetszet a belépő szakasz végére 400•550 szükül, ami pontosan megegyezik a mérőtér hasznos keresztmetszetével.

Az elem használatával egyenletes szükítést hoztunk létre, ami képes elhárítani a hirtelen szükülés okozta áramlási kép torzítását. Emellett az irodalom áttekintés [1-3] szerint az szükítés által létrejövő keresztmetszet csökkenés okozta légsebesség, illetve mozgási energianövekedés képes az adott keresztmetszeten átáramló levegő sebességeloszlás görbéjének egyenletesítésre. Annak érdekében, hogy szereléstechnikailag ne ütközzünk nagyobb nehézségekbe, a szükítés egyenletes ugyan, de nem szimmetrikus. A szélcsatorna felső falát a teljes szélcsatorna hosszon érintetlenül hagytuk.

A mérőteret elhagyó levegő a kilépő szakaszba lép, ami inverz kialakítású a belépő szakasszal. A kilépő szakasz után a ventilátor fogadóidom következik, amit egy 400•700-as négyszögletü légcsatorna elem lefenekelésével alakítottunk ki. A lefenekelt légcsatornára két NA300-as síkra ültetőt helyeztünk el.

\subsection{Szélcsatorna ellenállása, ventilátorok munkapontjának meghatározása}

A ventilátor fogadó idom okozta nyomásesés kiszámíthatatlansága miatt nehéz kalkulálni a rendszer ellenállását. Hogy ezt mégis meg tudjuk tenni a mérőtérben áramló levegő sebességét megmértük, melyből az átáramló közeg térfogatáramát meghatározva, becslést adhatunk a rendszerben létrejövő nyomásesésre. 
A mérést Prandtl cső segítségével végeztük, amit a mérőtérbe helyeztünk el. A mérések átlaga szerint a szélcsatorna mérőterében $4,72 \mathrm{~m} / \mathrm{s}$ légsebesség volt mérhetö. Ez alapján az átáramló közeg térfogatárama nagyságrendileg $3738 \mathrm{~m}^{3} / \mathrm{h}$, ami a ventilátorok jelleggörbéjét figyelembe véve $180 \mathrm{~Pa}$ össz nyomásesésnek felel meg.

\begin{tabular}{|c|c|}
\hline $\begin{array}{c}\Delta \mathrm{p} \text { veszteségek az adott elemeken összesen } \\
(\mathrm{v}=4,47 \mathrm{~m} / \mathrm{s}):\end{array}$ & $180 \mathrm{~Pa}$ \\
\hline Belépés & $0,7 \mathrm{~Pa}$ \\
\hline Konfúzor & $4,2 \mathrm{~Pa}$ \\
\hline Mérőtér & $0,7 \mathrm{~Pa}$ \\
\hline Diffúzor & $4,2 \mathrm{~Pa}$ \\
\hline $\begin{array}{c}\text { Hirtelen szükölés, ventilátorok egymásra } \\
\text { gyakorolt hatása, szereléstechnikai veszteségek }\end{array}$ & $170,2 \mathrm{~Pa}$ \\
\hline
\end{tabular}

1. táblázat: veszteségek az adott elemeken

A számítható elemek nyomásesését levonva a szerelés technikai és a ventilátor elhelyezés okozta plusz nyomásesés 170,2 Pa, ami nagyságrendi eltérés a többi elem ellenálláshoz képest. Ebböl is látható, hogy a pontos szereléssel és a ventilátorok közelségéből adódó áramlási kép zavarásának hatását csökkentve jelentősen lehet csökkenteni a rendszer ellenállást.

Annak köszönhetően, hogy a ventilátorok a szívott oldalon helyezkednek el, nem kell attól tartani, hogy az áramlás a mérötérben zavart lesz, de a rendszeren áthaladni képes térfogatáram mértékét átalakítással növelni lehet.

\section{Kalibrációs mérések}

\section{1. belépő keresztemtszet mérése}

Az első vizsgálatunk a szélcsatorna belépő keresztmetszetén átáramló levegő sebességének a vizsgálata volt. A vizsgálat során szélkerékkel és hődrótos sebességmérővel végeztünk méréseket. A vizsgált keresztmetszetet 9 részre osztva vizsgáltam. Minden esetben a kilenc mérési négyszög közepébe próbáltuk helyezni a mérő szenzorokat. A mérések átlagát az alábbi 2. táblázat foglalja össze:

\begin{tabular}{|c|c|c|c|}
\hline & Szélkerekes mérés & Hödrótos mérés & Eltérés \\
\hline Átlag szélsebesség & $4,29 \mathrm{~m} / \mathrm{s}$ & $3,7 \mathrm{~m} / \mathrm{s}$ & $0,59 \mathrm{~m} / \mathrm{s}(13,75 \%)$ \\
\hline Térfogatáram & $4324 \mathrm{~m}^{3} / \mathrm{h}$ & $3730 \mathrm{~m}^{3} / \mathrm{h}$ & $594 \mathrm{~m}^{3} / \mathrm{h}(13,75 \%)$ \\
\hline
\end{tabular}

2. táblázat: Mérések átlaga

\subsection{Mérőtér adott keresztmetszetének vizsgálata}

A mérőtér azon keresztmetszetét vizsgáltuk meg, amely síkban a későbbiekben mérendő tárgyak elhelyezésre kerülnek. A vizsgált keresztmetszetet a konfúzor szakasz és egy 1 méteres egyenes 
csőszakasz előzte meg. Egy síkban több ponton mértük az áramló levegő sebességét. Miután az általános sebességméréseket elvégeztünk sejtéseket kaptunk a belső térben áramló közeg azonos keresztmetszeten vett légsebesség eloszlásáról.

Az első méréseket Prandtl csővel végeztük el. A Prandtl, csővel a kijelölt keresztmetszet (400•550) középpontját vizsgáltuk. A Prandtl csővel nem végeztünk a középpont vizsgálatán kívül további méréseket szereléstechnikai nehézségek miatt, így a későbbi vizsgálatokban is a Prandtl cső mérőfejét a vizsgált tér középpontjába helyeztük el.

A mérés során $14 \mathrm{~Pa}$ nyomáskülönbséget mértünk, melyböl a külső légállapotokat figyelembe véve légsebességet számoltunk. A kiszámított érték: 4,72 m/s

A számítások alapján, a mérőtérben mért légsebesség és a belépő keresztmetszeten tapasztalható légsebességből számított, mérőtérben várható légsebesség közel megegyezik. A szélkerekes méréshez viszonyítva a mért és számított értékek között körülbelül 13\% eltérés tapasztalható, míg a hődrótos mérések alapján a mért és számított értékek közel megegyeznek.

Mivel a Prandtl csövet szerelés technikai okokból nem tudtuk több pozícióban elhelyezni, így nem tudtuk a keresztmetszeten tapasztalható sebességeloszlást felmérni. Ezért az AIRVENT ZME-100 mérőperemet használtuk fel. Fontos megjegyezni, hogy a méröperemmel a rajta átáramló közeg sebességét tudjuk meghatározni, viszont a mérőperem külső dimenziója keltette zavaró hatások és beömlési, áramlási veszteségek nem teszik lehetővé, hogy az adatokat egy az egyben megfeleltessük a szélcsatornában tapasztalható áramlási sebességgel. Viszont a mérőperem alkalmas arra, hogy a vizsgált keresztmetszeten átáramló közeg sebességeloszlását megbecsülhessük.

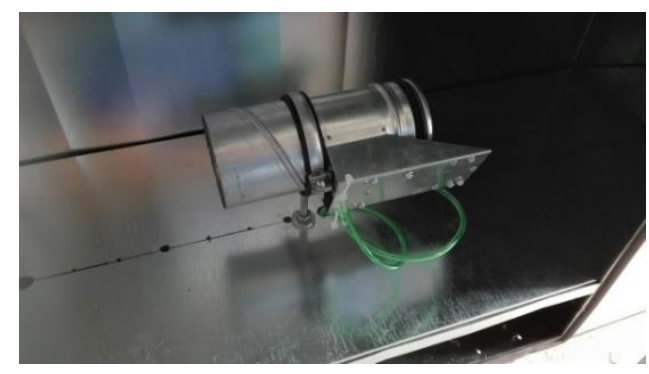

2. ábra: AIRVENT ZME-100 méröperem

\begin{tabular}{|c|c|}
\hline A szélcsatorna aljától 13cm-re a mérőperem középpontja & $19 \mathrm{~Pa}$ \\
\hline A szélcsatorna közepére helyezve & $17 \mathrm{~Pa}$ \\
\hline A szélcsatorna tetejétől 13cm-re a mérőperem középpontja & $16 \mathrm{~Pa}$ \\
\hline
\end{tabular}

3. táblázat: Nyomáskülönbségek

A mérésekből látható, hogy az áramlás nem tökéletesen egyenletes. Előzetes feltételezésünk szerint azt vártuk, hogy a csatorna közepén nagyobb nyomáskülönbséget mérünk a mérőperemmel, de a csatorna alján elhelyezett méröperem esetén történt a legnagyobb nyomásesés. 


\subsection{Szabályzószelep vizsgálata}

Miután a szélcsatornában uralkodó áramlásviszonyokat megvizsgáltuk, arra voltunk kíváncsiak, hogy a mérőtérbe helyezett csőrendszerben érvényesülnek e várakozásaink, vagy a behelyezett test a mérőtérben áramló közegre oly mértékü torzitó hatással lesz, hogy az a mérési eredményeket is befolyásolja. Ehhez olyan rendszert állítottunk össze, melynek a paraméterei gyárilag jól meghatározottak és egyszerüen változtathatók.

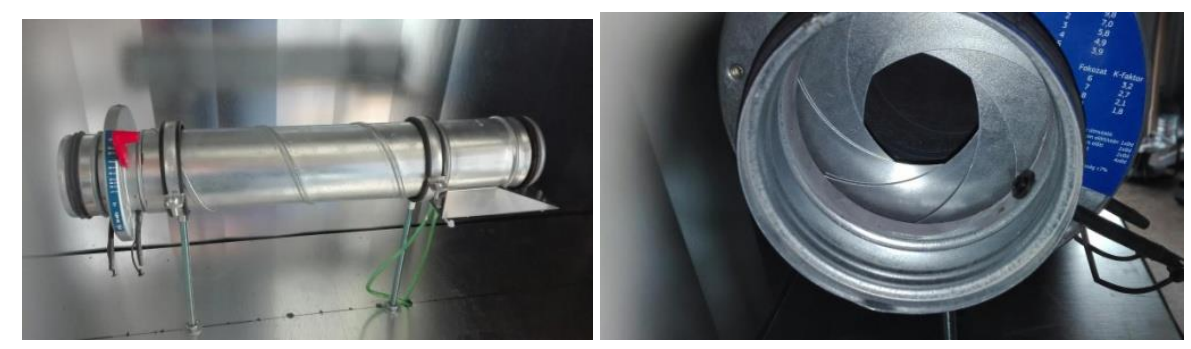

3. ábra: AIRVENT KBI100 szabályzószelep

A rendszerbe a levegő egy koncentrikus, hirtelen szükítést megvalósító szabályzó szelepen (AIRVENT KBI100) keresztül kerül be, majd 300 mm (3 D hosszúságú) hosszú csőszakasz után az előbbiekben is használt mérőperembe került. A méréseket a mérőperem csonkjainak segítségével végeztük. A mérés abból állt, hogy a szelep összes fokozata mellett megvizsgáltuk az átáramló levegő térfogatáramát, sebességét.

\begin{tabular}{|c|c|c|c|}
\hline $\begin{array}{c}\text { Szabályzószelep } \\
\text { állása }\end{array}$ & Nyomáskülönbség & Térfogatáram & Légsebesség \\
\hline 0 & $19 \mathrm{~Pa}$ & $0,0314 \mathrm{~m}^{5} / \mathrm{s}$ & $4 \mathrm{~m} / \mathrm{s}$ \\
\hline 2 & $16 \mathrm{~Pa}$ & $0,0288 \mathrm{~m}^{5} / \mathrm{s}$ & $3,67 \mathrm{~m} / \mathrm{s}$ \\
\hline 4 & $11 \mathrm{~Pa}$ & $0,0239 \mathrm{~m}^{3} / \mathrm{s}$ & $3,04 \mathrm{~m} / \mathrm{s}$ \\
\hline 6 & $6 \mathrm{~Pa}$ & $0,0176 \mathrm{~m}^{3} / \mathrm{s}$ & $2,24 \mathrm{~m} / \mathrm{s}$ \\
\hline 8 & $1 \mathrm{~Pa}$ & $0,0072 \mathrm{~m}^{5} / \mathrm{s}$ & $0,92 \mathrm{~m} / \mathrm{s}$ \\
\hline & 4. táblázat: Mérési eredmények \\
\end{tabular}

A 4. táblázatból látható, hogy a szelep állításával közel egyenletesen és arányosan változott a rendszeren átáramló levegő sebessége, valamint a térfogatáram. Tehát a szélcsatornánk mérőterében is érvényesültek a várt tulajdonságai a csőrendszernek, vagyis a behelyezett csőrendszer visszahatása a mérőtérben áramló közegre nem volt oly mértékü, hogy a mérés ne a vártak szerint alakuljon. Ez alapján arra következtetünk, hogy a szélcsatornánk összehasonlító mérések végzésére alkalmas.

\section{3. Összegzés}

A mérésekből következtethető, hogy szélcsatornánk további fejlesztésre szorul. A fejlesztéseket CFD szoftveres szimuláció fogja megelózni, hogy a kalkulált és valós változásokat össze tudjuk vetni. A megépített szélcsatorna jó alap e fejlesztések elvégzésére és a különbségek vizsgálatára. 


\section{Hivatkozások}

[1] Lajos Tamás; Az áramlástan alapjai; Budapest 2008

[2] Fekete-Menyhárt; A légtechnika elméleti alapjai; Budapest 1975

[3] Vad János; Ipari légtechnika jegyzet 